\title{
Project Gallery
}

\section{Grinding-stone features from the Pastoral Neolithic at Luxmanda, Tanzania}

Mary E. Prendergast ${ }^{1,}$, Katherine M. Grillo, ${ }^{2,}$, Agness O. Gidna ${ }^{3} \&$ Audax Z.P. Mabulla ${ }^{4}$

${ }^{1}$ Department of Anthropology, Rice University, USA

${ }^{2}$ Department of Anthropology, University of Florida, USA

${ }^{3}$ National Museum of Tanzania, Dar es Salaam, Tanzania

${ }^{4}$ Department of Archaeology and Heritage Studies, University of Dar es Salaam, Tanzania

* Authors for correspondence: mary@rice.edu \& kgrillo@ufl.edu

The initial spread of food production in eastern Africa is associated with livestock herding during the Pastoral Neolithic. Recent excavation at Luxmanda, Tanzania, a site dating to $c .3000 \mathrm{BP}$, revealed circular installations of lower grinding stones and numerous handstones. This discovery, unprecedented for this era, challenges previous ideas about pastoralist mobility and subsistence.

Keywords: Tanzania, Neolithic, pastoralism, mobility, subsistence

\section{Introduction}

The spread of livestock herding through sub-Saharan Africa marked a sea change from longstanding foraging lifeways and is thought to pre-date farming by millennia in parts of the continent (Marshall \& Hildebrand 2002). In Kenya and Tanzania, sites dating to the Pastoral Neolithic attest to early herding by 5000 BP and specialised pastoralism by 3000 BP (Figure 1). Luxmanda is the southernmost known Pastoral Neolithic site, and like other habitation sites of this era, it is characterised by middens with abundant pottery, lithics and the remains of livestock; a series of radiocarbon dates places initial occupation at c. 3000 cal BP (Prendergast et al. 2013; Grillo et al. 2018). Luxmanda's size (approximately 3ha) and good preservation allow reconstruction of the settlement through traditional and geophysical survey along with targeted excavation. Results from the 2018 season enable new interrogations of previous assumptions about Pastoral Neolithic communities, including that they were highly mobile, largely archaeologically invisible and almost exclusively reliant on livestock for food.

\section{Identification and excavation of stone features}

During geophysical survey in 2015, areas of high thermoremanent anomaly were detected and flagged for future investigation (Figure 2). In 2018, two such areas were identified as

Received: 14 July 2020; Accepted: 10 August 2020

(C) The Author(s), 2021. Published by Cambridge University Press on behalf of Antiquity Publications Ltd. This is an Open Access article, distributed under the terms of the Creative Commons Attribution licence (https://creativecommons. org/licenses/by/4.0/), which permits unrestricted re-use, distribution, and reproduction in any medium, provided the original work is properly cited. 


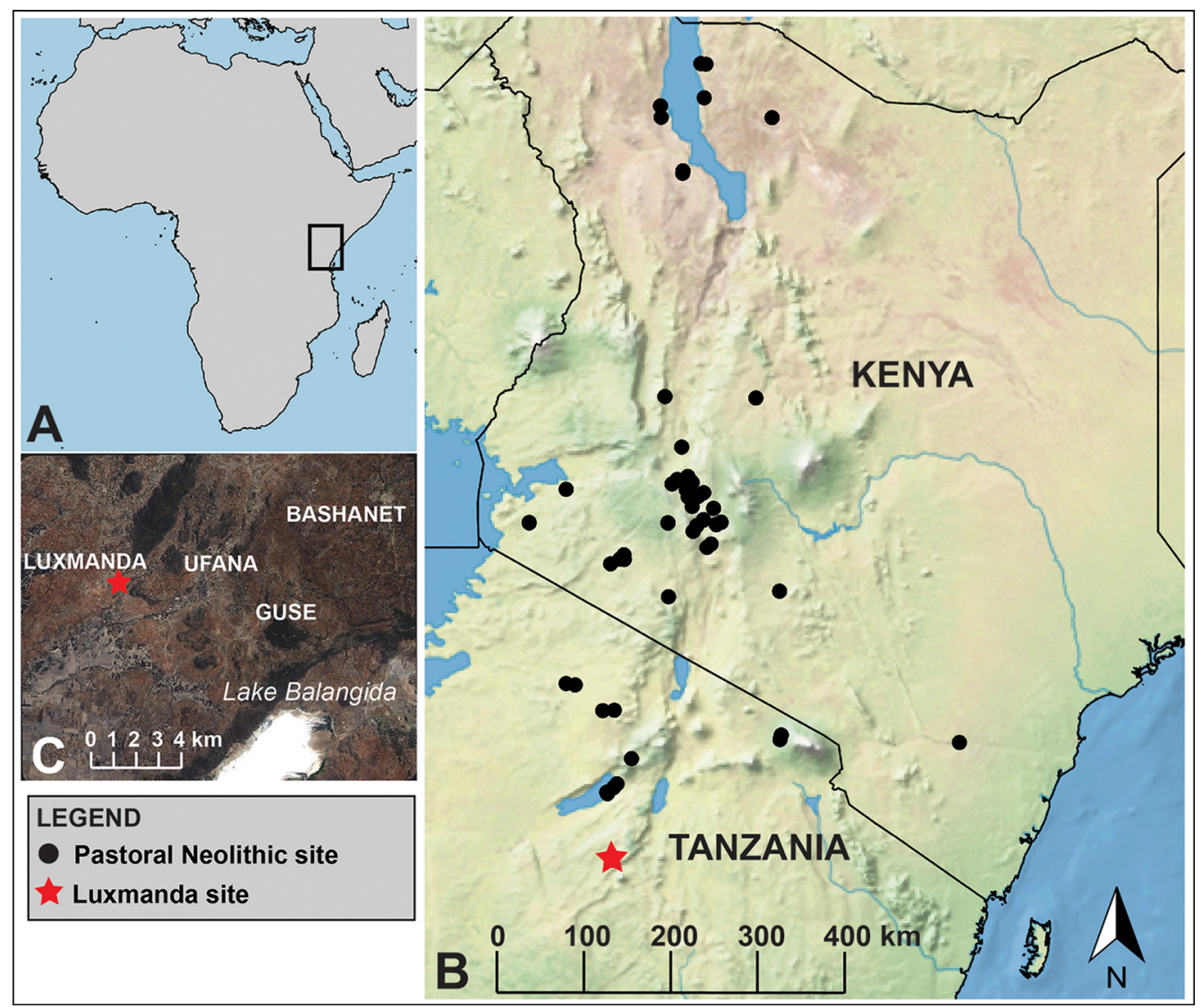

Figure 1. Map of Africa (A), showing the study region with Pastoral Neolithic sites indicated by black dots (B) and detail of the Luxmanda area (C). Basemap in (B) produced with Natural Earth; basemap in (C) is SPOT 1.5 resolution imagery licensed to M.E. Prendergast courtesy of the Harvard University Center for Geographic Analysis; map by M.E. Prendergast.

roughly circular concentrations of large, partially buried stones, mostly invisible under vegetation. These were cleared, mapped and named Stone Feature One (SF1; approximately $18 \mathrm{~m}^{2}$ ) and Stone Feature Two (SF2; approximately $90 \mathrm{~m}^{2}$ ) (Figure 3).

Prior to test excavations, we interviewed the landowners and several older residents of Luxmanda village about the stones. These informants had no prior knowledge of these features and did not view them as meaningful to the community within living memory. As cairns are a known feature of Pastoral Neolithic mortuary traditions, we proceeded with caution in a limited section of SF 1 and placed a $4 \mathrm{~m}^{2}$ trench. Given time constraints, the volume of cultural material found and the difficulty of excavation amongst stones, this area was reduced to $2 \mathrm{~m}^{2}$ (units 29-30) and then $1 \mathrm{~m}^{2}$ (unit 30).

\section{Excavation results}

Units 29-30, representing around 12.5 per cent of SF1, revealed a denser, deeper feature than expected from the surface, with no indication of burials (Figure 4). Twelve large lower

(C) The Author(s), 2021. Published by Cambridge University Press on behalf of Antiquity Publications Ltd. 


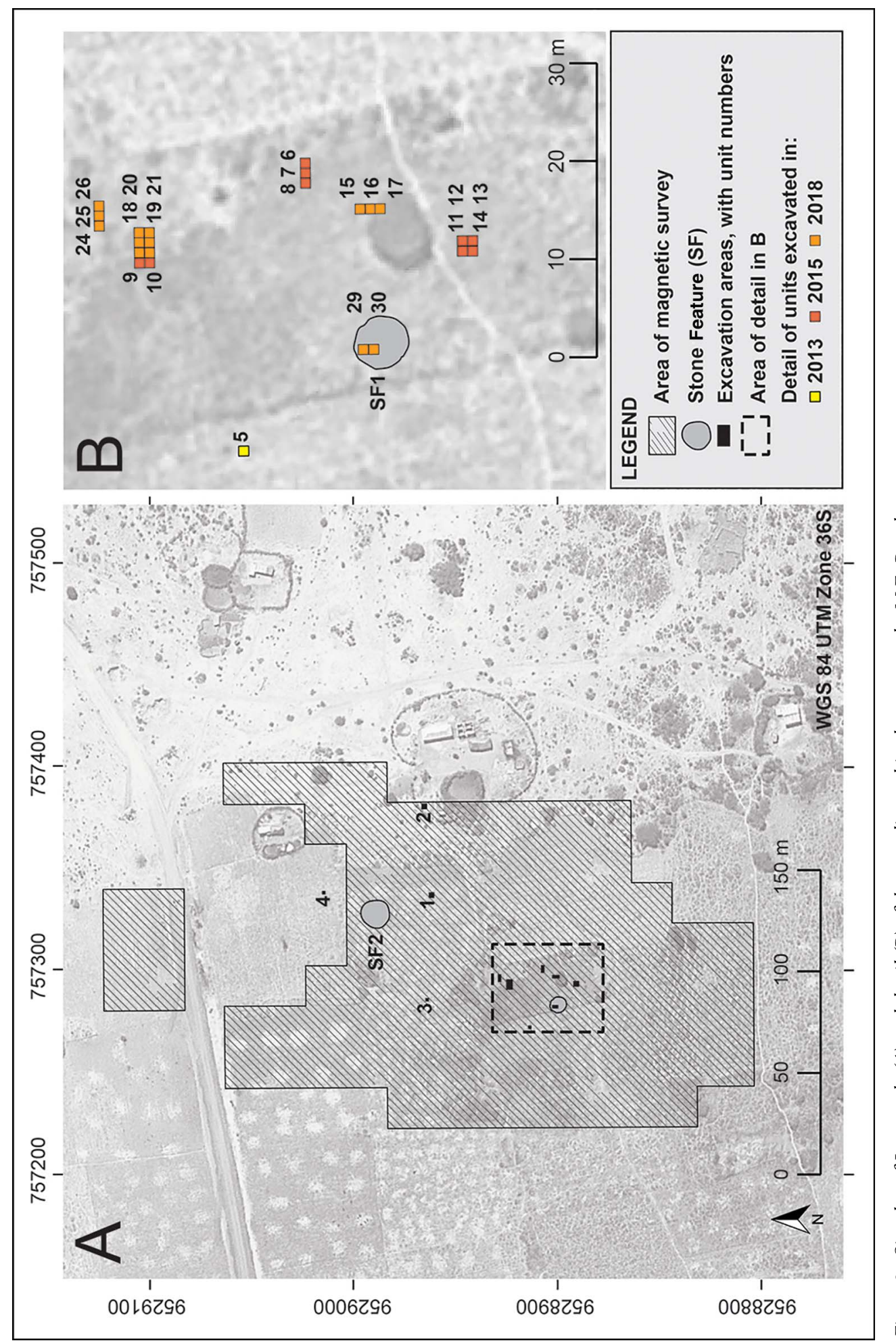

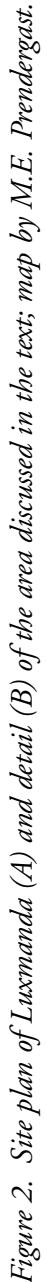

(C) The Author(s), 2021. Published by Cambridge University Press on behalf of Antiquity Publications Ltd. 


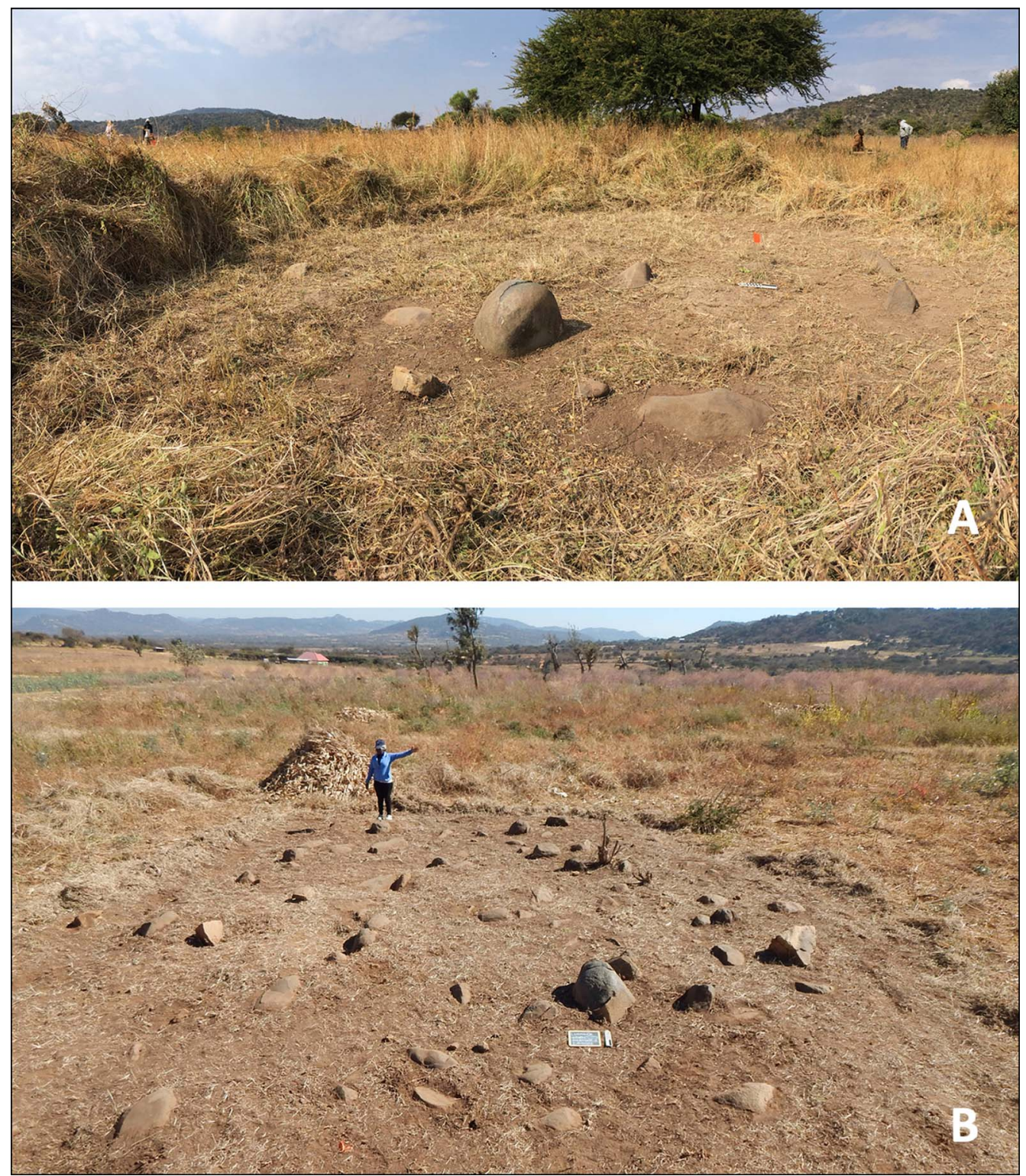

Figure 3. Stone Feature One prior to excavation (A) and the unexcavated Stone Feature Two (B); photographs by M.E. Prendergast.

grinding stones in this feature extend to the base of the excavation (Figure 5). They exhibit varied use-wear: they have been pounded, ground and pecked. One has a deep, cup-like depression. Some measure approximately $0.60 \mathrm{~m}$ at their greatest dimension, although around $0.40 \mathrm{~m}$ is more common. A grey, dung-derived deposit with an ashy appearance (designated PU 2-B) was found above and between the grinding stones. This deposit is similar to others found elsewhere across the site, and contained domestic refuse including pottery

(C) The Author(s), 2021. Published by Cambridge University Press on behalf of Antiquity Publications Ltd. 


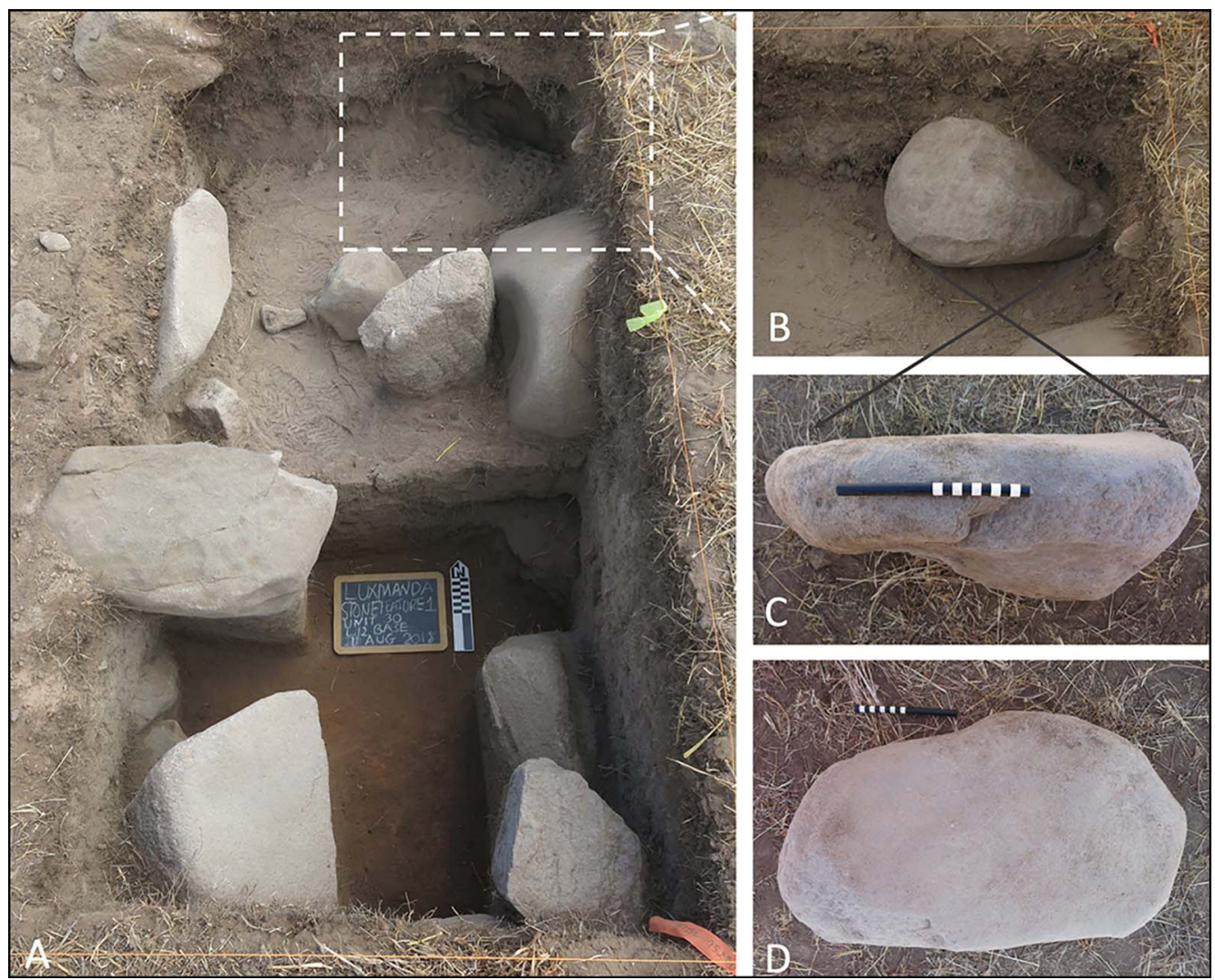

Figure 4. Excavation of units 29-30 (A), with details (B-D) of one lower grinding stone; photographs by K.M. Grillo.

attributable to the Pastoral Neolithic 'Narosura' tradition, lithic debris and livestock remains. Additional finds include an ostrich eggshell bead and 12 definitive (and 3 possible) handstones.

\section{Additional groundstone artefacts}

Groundstone artefacts were identified in situ during excavations elsewhere across the site and, much more commonly, on the surface, possibly brought up by tillage. All 46 in situ groundstone artefacts were measured and photographed (Figure 6), and 20 of these were dry- and wet-brushed under sterile conditions to sample for microbotanical remains. These samples are now being analysed; a technological analysis of the assemblage is also pending.

\section{Discussion and future research}

Grinding stones are well documented ethnographically in many parts of Africa, including eastern Africa (e.g. Arthur 2014; Shoemaker et al. 2017), but are archaeologically understudied, except in north-eastern Africa and the Horn, where they are associated with intensive wild plant processing and/or agriculture (e.g. Nixon-Darcus \& D’Andrea 2017;

(C) The Author(s), 2021. Published by Cambridge University Press on behalf of Antiquity Publications Ltd. 


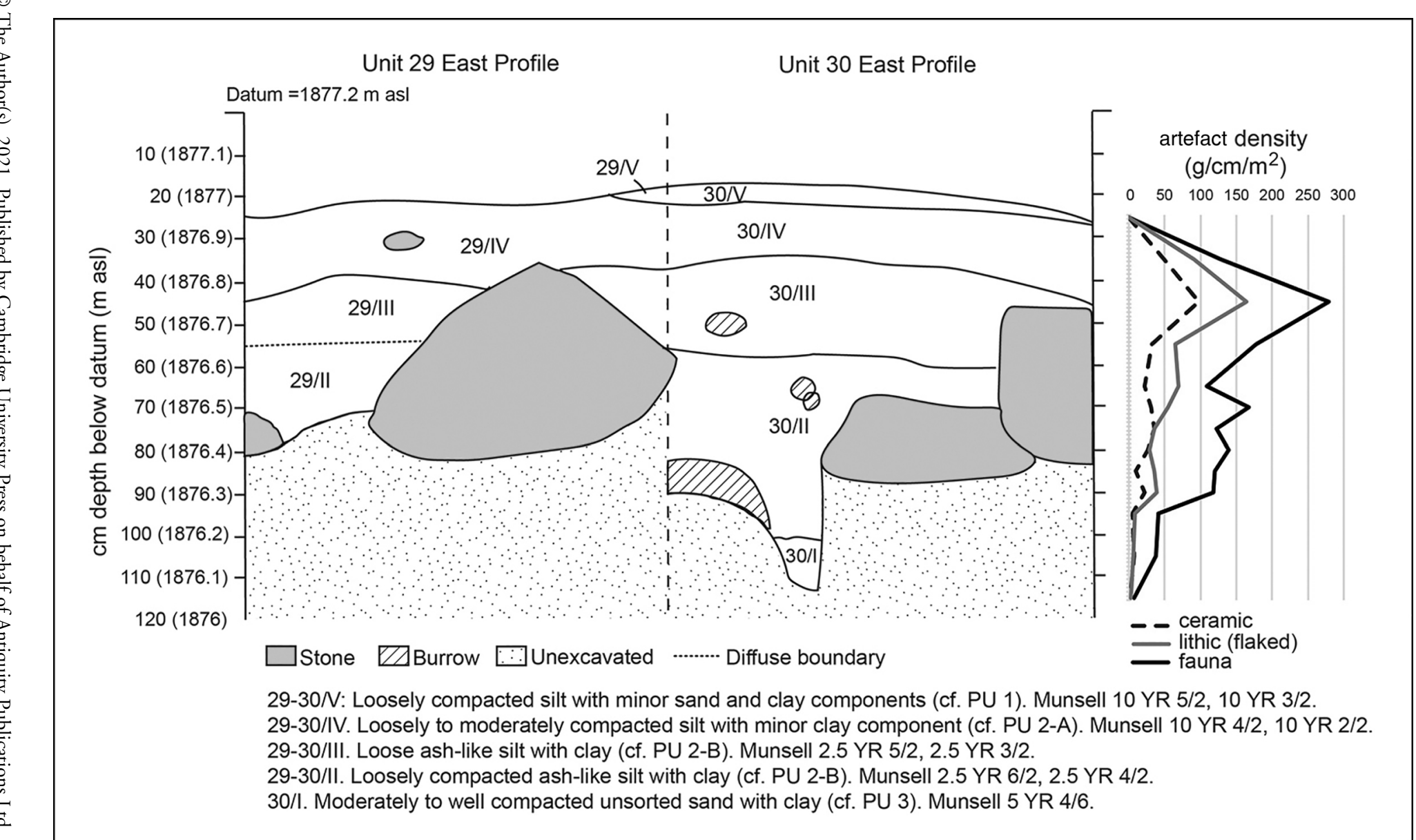

Figure 5. East profile of units 29-30, with artefact density by depth; PU refers to pedostratigraphic units; illustrations by M.E. Prendergast. 


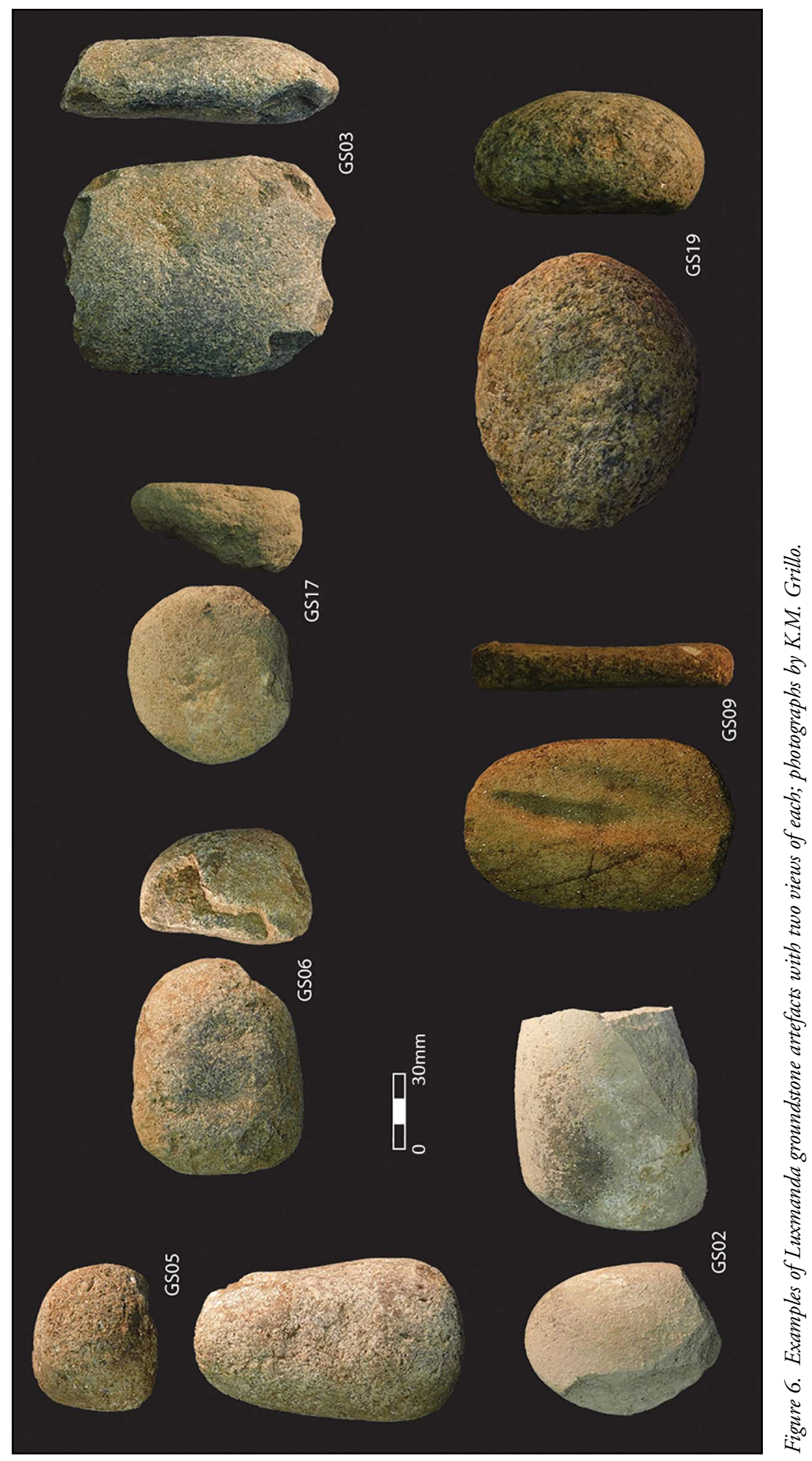

(C) The Author(s), 2021. Published by Cambridge University Press on behalf of Antiquity Publications Ltd. 
Lucarini \& Radini 2019). Shoemaker and Davies's (2019) comprehensive review of Pastoral Neolithic grinding stones in eastern Africa demonstrates their potential to illuminate culinary, crafting and mortuary traditions. At least ten Pastoral Neolithic sites (six of them funerary) report lower grinding stones. In many cases these are marked by ochre stains, whereas no obvious traces were seen at Luxmanda. The Luxmanda artefacts also tend to be larger and thicker than many of those reported as slabs (Shoemaker \& Davies 2019: tab. 2), are spatially concentrated in a way not previously reported from habitation sites, and are not-based on testing thus far-associated with burials. In these senses, the Luxmanda stone features appear to be unique for the Pastoral Neolithic. Many of the excavated lower grinding stones are too large to be easily transportable - prompting us to question narratives that Pastoral Neolithic herders were always highly mobile.

The size of the assemblage and morphology of the lower grinding stones seem to suggest intensive processing of plant foods. Linguistic evidence, site locations, the presence of axes and ethnographic analogies have been cited to suggest Pastoral Neolithic cereal cultivation (Robertshaw \& Collett 1983). This has long been contested on the grounds of a lack of direct evidence (Bower 1991; Crowther et al. 2018); archaeobotanical sampling has generally been limited, however. Other uses of some of the Luxmanda groundstone artefacts are possible: anvils, for example, may have been used to pound bone for marrow and grease extraction, a scenario consistent with zooarchaeological evidence (Grillo et al. 2018) and lipid residues (Grillo et al. 2020). We do not yet know why or how the grinding stones were aggregated into these circular features, but we suggest they were intentionally deposited, before the end of their potential use-lives, with dung and domestic refuse discarded on top. Although additional research is needed and is underway, we suggest Luxmanda's grinding-stone features have the potential to transform understandings of Pastoral Neolithic mobility patterns, food systems and communal social behaviours.

\section{Acknowledgements}

Permission was granted by the Tanzanian Commission for Science and Technology (2018-327-NA-2012-50) and Antiquities Division (13/2017/2018). We are grateful to our hosts in Luxmanda and our teammates, especially D. Contreras, T. Fitton and M. Storozum for their help identifying these features.

\section{Funding statement}

Fieldwork was supported by a National Geographic Society grant to M.E. Prendergast (NGS-196R-18), a Wenner-Gren Foundation grant to K.M. Grillo, and a Palaeontological Scientific Trust grant to A.O. Gidna.

\section{References}

ARTHUR, J. 2014. Culinary crafts and foods in southwestern Ethiopia: an ethnoarchaeological study of Gamo groundstones and pottery. African Archaeological Review 31: 131-68. https://doi.org/10.1007/s10437-014-9148-5
Bower, J. 1991. The Pastoral Neolithic of East Africa. Journal of World Prehistory 5: 49-82. https://doi.org/10.1007/BF00974732

Crowther, A., M.E. Prendergast, D.Q. Fuller $\&$ N. Borvin. 2018. Subsistence mosaics, forager-farmer interactions, and the transition to

(C) The Author(s), 2021. Published by Cambridge University Press on behalf of Antiquity Publications Ltd. 
food production in eastern Africa. Quaternary International 489: 101-20. https://doi.org/10.1016/j.quaint.2017.01.014

Grillo, K.M., M.E. Prendergast, D. Contreras, T. Fitton, A.O. Gidna, S.T. Goldstein, M.C. Knisley, M. Langley \& A.Z.P. Mabulla. 2018. Pastoral Neolithic settlement at Luxmanda, Tanzania. Journal of Field Archaeology 43: 102-20.

https://doi.org/10.1080/00934690.2018. 1431476

GriLlo, K.M. et al. 2020. Molecular and isotopic evidence for milk, meat and plants in prehistoric eastern African herder food systems. Proceedings of the National Academy of Sciences of the USA 117: 9793-99.

https://doi.org/10.1073/pnas.1920309117

LuCARINI, G. \& A. Radini. 2019. First direct evidence of wild plant grinding process from the Holocene Sahara: use-wear and plant micro-residue analysis on ground stone tools from the Farafra Oasis, Egypt. Quaternary International 555: 66-84. https:/doi.org/10.1016/j.quaint.2019.07.028

Marshall, F. \& E. Hildebrand. 2002. Cattle before crops: the beginnings of food production in Africa. Journal of World Prehistory 16: 99-43.

https://doi.org/10.1023/A:1019954903395
Nixon-Darcus, L. \& A.C. D’Andrea. 2017.

Necessary for life: studies of ancient and modern grinding stones in highland Ethiopia. African Archaeological Review 34: 193-223. https://doi.org/10.1007/s10437-017-9252-4

Prendergast, M.E., A.Z.P. Mabulla, K.M. Grillo, L. Broderick, O. Seitsonen, A.O. Gidna \& D. Gifford-Gonzalez. 2013. Pastoral Neolithic sites on the southern Mbulu Plateau, Tanzania. Azania: Archaeological Research in Africa 48: 498-520. https://doi.org/10.1080/0067270X.2013.841927

Robertshaw, P. \& D. Collett. 1983. The identification of pastoral peoples in the archaeological record: an example from East Africa. World Archaeology 15: 67-78.

Shoemaker, A.C. \& M.I.J. Davies. 2019. Grinding-stone implements in the eastern African Pastoral Neolithic. Azania: Archaeological Research in Africa 54: 203-20.

https://doi.org/10.1080/0067270X.2019. 1619284

Shoemaker, A.C., M.I.J. Davies \& H.L. Moore. 2017. Back to the grindstone? The archaeological potential of grinding-stone studies in Africa with reference to contemporary grinding practices in Marakwet, northwest Kenya. African Archaeological Review 34: 415-35. 